\title{
Kaolin Uygulamalarının Bazı Fasulye Çeşitlerinde Tanede Protein ve Bazı Mineral Maddeler Üzerine Etkisi
}

\author{
Nuri Yılmaz ${ }^{1}$ (D), Tansu Uzun ${ }^{1}$
}

${ }^{1}$ Ordu Üniversitesi, Ziraat Fakültesi, Tarla Bitkileri Bölümü, Ordu

${ }^{2}$ Ordu Üniversitesi, Fen Bilimleri Enstitüsü, Tarla Bitkileri Anabilim Dalı, Ordu

Geliş Tarihi / Received Date: 17.06.2021

Kabul Tarihi / Accepted Date: 14.09.2021

Özet

2017 Yılında Ordu Üniversitesi Ziraat Fakültesi deneme arazisinde yürütülen bu araştırmada, bazı fasulye çeşitlerinde (Göksun, Göynük-98, Akman-98) kaolin uygulamalarının tanede protein ve bazı mineral maddeler üzerine etkisinin belirlenmesi amaçlanmıştır. Araştırma, tesadüf bloklarında faktöriyel düzenleme deneme desenine göre üç tekrarlamalı olarak yürütülmüş ve Kaolin dozları \%0, \%2.5, \%5, \%7.5 ve \%10 solüsyon olarak hazırlanacak hazırlanarak bitkinin çiçeklenme başlangıcı periyodunda bütün aksamına uygulanmıştır. Araştırmada çeşitler arasında protein ve bazı mineral maddeler açısından istatistiksel olarak önemli farklılıkların olduğu gözlenmiştir. Araştırma sonucunda Göynük çeşidi, protein ve N bakımından Akman 98 çeşidi ise $P, K$ ve Ca bakımından dikkat çekmiştir. Diğer taraftan kaolin uygulamaları protein ve N, P, K ve Ca' ya istatistiksel olarak etki göstermemiştir.

Anahtar Kelimeler: çeşit, kuru fasulye, mineral maddeler, protein, kaolin

\section{Determination of the Effect of Kaolin Applications on Protein of Grain and Some Mineral Matters in Some Beans Varieties}

\begin{abstract}
The research was carried out on the trial land of Ordu University Faculty of Agriculture in 2017. The aim of this study was to determine the kaolin effects on yield, yield components and grain quality in some bean cultivars (Göksun, Göynük-98, Akman-98). The kaolin doses (0\%, 2.5\%, 5\%, 7.5\%, 10\%) were used at the beginning of flowering period of the plants and applied to all parts. The experiment was carried out in randomized blocks in a factorial arrangement with three replications. As a result of the statistical analysis, it was observed that there were statistically significant differences between the cultivars in terms of protein and some mineral substances. As a result of the research, Göynük variety attracted attention in terms of protein and $\mathrm{N}$ and Akmn 98 variety in terms of $\mathrm{P}, \mathrm{K}$ and $\mathrm{Ca}$. On the other hand, kaolin applications did not statistically affect protein and $\mathrm{N}, \mathrm{P}, \mathrm{K}$ and Ca.
\end{abstract}

Keywords: variety, haricot bean, minerals, protein, kaolin 


\section{Giriş}

Besin maddesi artışı, dünya nüfusunun günümüzde hızla artmasına oranla istenilen düzeyde değildir. Dünya üzerinde birçok ülkede açlık ve düzensiz beslenmenin büyük bir problem olduğu bilinmekte ve her sene binlerce insanın ölmesine neden olmaktadır (Ünver vd., 1999).

Gelişmiş ülkeler dışındaki ülkelerin hemen tümünde, kalori ve protein yetersizliği sorunu önemli düzeyde yer almaktadır. Bilindiği gibi hayvansal ürünler en önemli protein kaynaklarıdır. Fakat bu ürünlerin hem maliyetleri yüksektir hem saklanmaları zordur hem de çabuk bozulurlar. Bu sebeplerden dolayı günümüzde daha ucuza elde edilebilen ve uzunca süre bozulmadan saklanabilen bitkisel protein üretimini artırma olanakları üzerinde durulmaktadır. Protein ihtiyacının karşılanmasında yemeklik baklagiller önemli bir yere sahiptir. Kuru olarak kullanılan tanelerde \%18-36 arasında protein bulunduran baklagiller vitaminlerce de zengindir.

Ülkemizde tarım arazilerinin gün geçtikçe azalması, hızla artan nüfus yoğunluğu olumsuz çevre koşulları gibi nedenlerden dolayı insanlar yeterli olarak besin ihtiyacını karşılayamamaktadır. Bundan dolayı yeterli ve dengeli beslenmede yemeklik tane baklagiller protein değeri açısından önemli bir yere sahip olmakla birlikte daha az maliyetle elde edilen besin kaynağını oluşturmaktadır.

Yemeklik tane baklagillerin insan beslenmesi yanında, sapları ve taneleri, hayvan beslenmesinde de kullanılabilmektedir. Hayvan beslenmesinde bir ton baklagil sapı sekiz ton tahıl sapına eşdeğer olmaktadır (Şehirali, 1979).

Yemeklik tane baklagiller azot fiksasyonunu sağlamalarının yanı sıra toprakta açılan kanallarda mikroorganizma faaliyetlerini hızlandırırlar ve böylece kök bölgesinde canlıı̆ın artış göstermesine katkıda bulunurlar. Aynı zamanda açtıkları derin kök kanallar sayesinde toprak sıkışmasını önlerler (Uysal, 2002).

Fasulye iklim koşulları açısından seçiciliği en fazla olan yemeklik tane baklagil türüdür. Bir alandaki fasulye yetiştiriciliğini, verim ve kaliteyi fiziksel, (sıcaklık, yağış, gün uzunluğu, topografya, toprak tipi vs.), biyolojik (hastalık ve zararlılar) ve sosyo-ekonomik faktörler etkilemektedir (Pekşen, 2005).

Fasulye sıcak iklimde yetişen bir baklagil bitkisidir. Ekim zamanı Anadolu'da mayıs ayının ilk haftasından itibaren başlamaktadır. Gelişim dönemi güneşli ve sıcak havalara denk geldiğinden dolayı mümkün olduğunca sulanmasına özen gösterilmelidir. Bundan dolayı yetişme döneminde su stresi ve yaprak yanıklığı gibi zararlar görülebilmektedir. Bu zararlardan korunması amacı ile bitkinin toprak üstü aksamına koruyucu doğal maddeler kullanılabilmektedir. Bu anlamda kullanılan ürünlerden bir tanesini de kaolin kilidir.

Yapılan denemeler ve çalışmalar sonucunda geliştirilen kaolinin farklı doz uygulamaları bitki üst aksamına uygulandığı zaman kutikulayı andıran ve koruma işlevi gören, beyaz, ışığı yansıtıcı bir tabaka oluşturarak canlı ve cansız çevre şartlarına karşı koruma sağlar. Kaolin kili \%100 doğaldır ve suda çözülebilen bir formdadır. Dünya' da canlı ve cansız stres faktörlerinde kaolin uygulaması 'Partikül film teknolojisi' şekliyle de bilinmektedir (Vanoğlu, 2015).

Aşındırma ve şişme özelliği olmayan beyaz, ince, gözeneksiz, içeriğinde Aliminosilikat (Al4Si4O10(OH)8) bulunan, suda eriyebilen kaolin aspirin gibi tabletlere ve kâğıda beyazlık vermesi amacı ile de kullanımı bulunmaktadır. İnsan sağlığına herhangi bir zararı bulunmadığı için çoğu ilaçların ve diş macunlarının yapısında kaolin bulunmaktadır. Meyve ve yaprak yüzeyine gelen ışığın büyük bir kısmını yansıtır ve fotosentezi artırır. Kaolin, farklı muamelelerden geçirilen beyaz kil mineralidir (Glenn vd., 1999).

Bitki örtüsüne püskürtülen kaolin, bitkinin yaprakları, sapları, gövdesi ve meyvelerinde oluşturduğu ince film tabakası ile bitkinin sıcaklık ve su stresini azalttığı bilinmektedir (Rosati vd., 2006). Rosati vd. (2006); sorgum (Stanhill vd., 1976), pamuk (Moreshet vd. 1979), domates (Srinivasa Rao, 1985) ve yer fıstığı (Soundara Rajan, 1981) gibi bitkilerde bu çalışmaların yapıldığını bildirmektedir. Bu çalışmalarının bitki verimi ile sınırlı kaldığı; alınan sonuçlara bakıldığında belli koşullarda bazı bitkilerde verim artışı sağlandığı belirtilmiştir (Yiğitarslan, 2010). Bununla birlikte yemeklik baklagillerde konuyla ilgili çalışma 
oldukça sınırlıdır. Verim artışına etkisi yönünden birkaç çalışmaya rastlanılmıştır ancak protein ve besin maddelerine etkisi konusunda herhangi bir çalışmaya rastlanılmamıştır. İnsan beslenmesinde önemli bir yer tutan besin elementlerinin bitkilerde zenginleştirilmesi yoluyla insanların sağlık sorunlarının azaltılması ülkelerdeki besin elementi eksikliği sorunları ile mücadelede hızlı ve etkili bir rol oynayacaktır. Bu nedenle araştırma önem arz etmektedir. Bu bağlamda yapılan bu çalışmayla Ordu ekolojik koşullarında yetiştirilen fasulye bitkisinin farklı çeşitlerinde kaolin kili uygulamalarının tanede protein ve $\mathrm{N}, \mathrm{P}, \mathrm{K}, \mathrm{Ca}$ gibi bazı mineral maddelere etkisinin belirlenmesi amaçlanmıştır.

\section{Materyal ve Yöntem}

\section{Materyal}

Çalışma 2017 yılı ilkbahar-yaz döneminde Ordu Üniversitesi Ziraat Fakültesi deneme arazisinde yürütülmüştür. Deneme alanı Ordu iline bağlı Altınordu ilçesinde, Doğu ve Orta Karadeniz'in ayrılma sınırı olan Melet nehrine yakın yerde bulunmakta olup Orta Karadeniz bölümünde yer almaktadır.

Ordu ili, Orta Karadeniz Bölgesi'nin ılıman iklim özelliklerini yansıtmaktadır. İlde yağışların büyük bir kısmı kış ve sonbaharda düşerken, özellikle yaz aylarında düşen yağışlar bitkisel üretim için yetersizdir. Fasülye yetiştirme dönemine ait uzun yıllar ortalama sıcaklık $21.7^{\circ} \mathrm{C}$, toplam yağış miktarı $285.5 \mathrm{~kg} / \mathrm{m} 2$ iken, bu değerler 2017 yılında sırasıyla $23.1{ }^{\circ} \mathrm{C}$ ve $125.0 \mathrm{~kg} / \mathrm{m}^{2}$ olmuştur. Yetiştirme döneminde uzun yıllar nispi nem ortalaması \% 73.4 iken, 2017 yılında \% 71.5 olmuştur (Ordu Meteoroloji Müdürlüğü, 2018).

Deneme tarlasından 0-30 cm derinlikten alınan toprak örnekleri Giresun Fındık Araştırma Enstitüsünde analiz edilmiş ve sonuçlar Tablo 1'de gösterilmiştir. Tablo 1'de görüldüğü üzere deneme alanı toprakları killi bir yapıya sahip olup, pH değeri 6.88 (çok hafif asit) dir.

Çalışmada, materyal olarak Karadeniz Tarımsal Araştırma Enstitüsünden getirilen Göynük-98 (bodur), Akman-98 (yarı sarılıcı) ve Göksun (sarılıcı) çeşitleri kullanıımıştır.

Tablo 1. Deneme Tarlasından Alınan Toprak Analiz Sonuçları

\begin{tabular}{cc}
\hline Özellik & Sonuç \\
\hline Bünye & Killi toprak \\
Ph & 6.88 \\
Kireç $(\%)$ & 1.24 \\
Tuzluluk & 0.70 \\
Organik Madde $(\%)$ & 0.58 \\
N (\%) & 0.03 \\
P (ppm) & 8.19 \\
K (ppm) & 102.0 \\
Ca (ppm) & 4343.0 \\
Mg (ppm) & 769.8 \\
Fe (ppm) & 3.67 \\
Mn (ppm) & 1.44 \\
Zn (ppm) & 0.098 \\
Cu (ppm) & 0.743 \\
\hline
\end{tabular}

\section{Yöntem}

Çalışma, tesadüf bloklarında faktöriyel düzenleme deneme desenine göre 3 tekerrürlü olarak yürütülmüştür. Parsel boyu $4 \mathrm{~m}$, eni $2.5 \mathrm{~m}$ olan çalışmada ekimler sıra üzeri $15 \mathrm{~cm}$, sıra arası $50 \mathrm{~cm}$ olacak şekilde 7 Haziran 2017 tarihinde elle yapılmıştır. Her parsele ekimle birlikte $3.6 \mathrm{~kg} \mathrm{~N} / \mathrm{da}, 8-10 \mathrm{~kg}$ P2O5/da hesabıyla gübre verilmiştir. Kaolin uygulamaları çiçeklenme dönemi başlangıcında solüsyon olarak hazırlanıp bitkinin bütün aksamına uygulanmıştır. Uygulama dozları; 0, \%2.5, \%5.0, \%7.5, \%10 olup, dozlar 5 litrelik suyun içerisine ayrı ayrı 125, 250, 375 ve 500 gramlık kaolin killeri tartılıp hazırlanmıştır. Hasat 18 Eylül-24 Eylül 2017 tarihleri arasında yapıımıştır. 


\section{Denemede yapılan gözlem ve ölçümler}

Tane Protein Oranı (\%): Khejdal yöntemi ile Nx6.25 formülüyle hesaplanmıştır.

Tanede Mineral Madde iç̧eriği (N,P,K,Ca): Çalışma sonucunda elde edilen tanelerin öğütülmesinden sonra uygun yöntemler kullanılarak mineral madde oranları \% olarak belirlenmiştir.

Tanede Toplam Azot (N) İçeriği: Khejdal yöntemine göre belirlenmiştir (Bremmer, 1965).

Tane Fosfor ( $P$ ) iç̧eriği: Kuru yakma metoduna göre elde edilen çözeltideki toplam fosfor (P) vanodomolibdo fosforik sarı renk metoduna göre spektrofotometrede belirlenmiştir (Kacar ve İnal, 2008).

Tane Potasyum (K) iç̧eriği: Kuru yakma metodu ile elde edilen çözeltideki potasyum (K) flymfotometresiyle belirlenmiştir (Kacar \& İnal 2008).

Tane Kalsiyum (Ca) İçeriği: Kuru yakma metoduyla elde edilmiş çözeltideki kalsiyum (Ca) flymfotometresi ile belirlenmiştir (Kacar ve İnal 2008).

Yapılan çalışmada ele alınan özellikler SAS-JMP.13.0 istatistik paket programında varyans analizine tabii tutulmuştur ve LSD çoklu karşılaştırma testi kullanılmıştır.

\section{Bulgular ve Tartışma}

\section{Tanede Protein Oranı (\%)}

Denemede kullanılan fasulye çeşitlerine ve kaolin uygulamalarına ait tanede protein ortalamaları ve istatistiksel grup karşılaştırmaları Tablo 2'de verilmiştir. Tablodan da görüldüğü üzere çeşitlerin protein oranına etkisi istatistiksel olarak önemli $(P<0.05)$ çıkmıştır. En yüksek protein oranı \%25.69 ile Göynük98 çeşidinden elde edilmiş, bunu sırasıyla \%24.18 ile Akman-98 ve \%23.48 ile Göksun çeşidi izlemiştir. Akman-98 çeşidi ile Göksun çeşidi aynı istatistik grubunda yer alırken Göynük-98 çeşidi protein oranı bakımından her iki çeşitten de üstün bulunmuştur. Konuyla ilgili olarak Düzdemir (1998), fasulyede tanede protein oranını \% 18.99-29.17 arasında, Cengiz (2007), \%19.25-23.66 arasında belirlemişledir. Bulgularımız ilgili araştırıcıların sonuçları ile uyum halinde olduğu görülmektedir.

Kaolin uygulamasının protein oranına etkisi önemsiz olmuştur. Ayrıca, çeşit $x$ kaolin uygulamaları interaksiyonu da istatistiksel olarak önemli çıkmamıştır. Çalışmada protein oranları \%22.24-\%26,35 arasında tespit edilmiştir (Tablo 2). Yiğitarslan (2010), konuyla ilgili Ankara koşullarında yaptığı çalışmada Kaolin uygulamalarının tanedeki protein oranını artırdığını belirtmektedir. Araştırmalar arasındaki farklıı̆ın çevresel faktörlerden ve uygulama farklılıklarından kaynaklandığı düşünülmektedir.

Tablo 2. Kaolin Dozlarının ve Fasulye Çeşitlerinin Tanede Protein Oranına (\%) Ait Ortalamaları

\begin{tabular}{lcccccc}
\hline \multirow{2}{*}{ Çeşitler } & \multicolumn{7}{c}{ Kaolin } \\
\cline { 2 - 6 } & 0 & 2.5 & 5 & 7.5 & 10 & Ortalama \\
\hline Göksun & 23.28 & 23.28 & $\mathbf{2 2 . 2 4}$ & 24.58 & 24.01 & 23.48 B \\
Göynük-98 & 24.68 & $\mathbf{2 6 . 3 5}$ & 26.18 & 25.97 & 25.26 & $25.69 \mathrm{~A}$ \\
Akman-98 & 24.35 & 23.95 & 24.51 & 24.72 & 23.37 & $24.18 \mathrm{~B}$ \\
Ortalama & 24.10 & 24.53 & 24.31 & 25.09 & 24.21 & \\
\hline
\end{tabular}

LSD(çeşit): 1.48

\section{Tanede Toplam N İçeriği (\%)}

Denemeye alınan kuru fasulye çeşitleri ve kaolin uygulamalarının tanede toplam $\mathrm{N}$ içeriği üzerine etkisine ait ortalamalar ve istatistiksel gruplar Tablo $3^{\prime}$ de verilmiştir.

Tablo incelendiğinde tanede $\mathrm{N}$ içeriği bakımından çeşitler arasında önemli $(\mathrm{P}<0.05)$ fark olduğu görülmektedir. N (\%) içeriği ortalaması en fazla \% 4.11 ile Göynük-98 çeşidinden elde edilmiş ve bu çeşit ile diğer çeşitler arasında belirlenen farklar önemli bulunmuştur. En düşük değer ise \%3.75 ile 
Göksun çeşidinde görülmüş ancak, Göksun çeşidi ile Akman-98 çeşidi arasında fark önemsiz bulunmuştur. (Tablo 3).

Tablo 3. Kaolin Dozlarının ve Fasulye Çeşitlerinin Tanede Toplam N İçeriğine (\%) Ait Ortalamaları

\begin{tabular}{lcccccc}
\hline \multirow{2}{*}{ Çeşitler } & 0 & 2.5 & 5 & 7.5 & 10 & Ortalama \\
\cline { 2 - 7 } & 3.72 & 3.72 & 3.56 & 3.93 & 3.84 & $3.75 \mathrm{~B}$ \\
\hline Göksun & 3.95 & $\mathbf{4 . 2 1}$ & 4.18 & 4.15 & 4.04 & $4.11 \mathrm{~A}$ \\
Göynük-98 & 3.89 & 3.83 & 3.92 & 3.95 & 3.74 & $3.87 \mathrm{~B}$ \\
Akman-98 & 3.85 & 3.92 & 3.89 & 4.01 & 3.87 & \\
Ortalama & &
\end{tabular}

LSD(çeşit): 0.23

Kaolin uygulamalarında tanede toplam $\mathrm{N}$ içeriği \%3.56-4.41 arasında tespit edilmiş ve bu özellik bakımından kaolin uygulamalarının etkisi ve kaolin $\mathrm{x}$ çeşit interaksiyonu istatistiksel anlamda önemsiz bulunmuştur. Bununla birlikte çeşitlerin ortalaması olarak değerlendirildiğinde \%7,5 kaolin uygulamasına kadar $\mathrm{N}$ içeriği artış eğiliminde olduğu, daha sonra tekrar azalış eğilimine geçtiği görülmüştür. Yiğitarslan (2010), konuyla ilgili Ankara koşullarında yaptığı çalışmada Kaolin uygulamalarının tanedeki N içeriğini artırdığını belirlemiştir. Bulgular arasında kısmen bir benzerliğin olduğu görülmektedir. Araştırmalar arasındaki farklııı̆ın çevresel faktörlerden ve uygulama farklııklarından kaynaklandığı düşünülmektedir.

\section{Tane P İçeriği (\%)}

Denemede kullanılan fasulye çeşitlerine ve kaolin uygulamalarına ait tanede $\mathrm{P}$ içeriği ortalamaları ve istatistiksel grup karşılaştırmaları Tablo 4 'de verilmiştir. Tablodan da görüldüğü üzere çeşitlerin tanedeki $\mathrm{P}$ içeriğine etkisi istatistiksel olarak çok önemli $(\mathrm{P}<0.01)$ olmuştur. Çeşitlere ait tanede $\mathrm{P}$ içeriği değerleri \%0.51-\%0.59 arasında değişim göstermiştir. En yüksek $P$ içeriği \%0.59 ile Akman-98 çeşidinden elde edilmiş, bunu sırasıyla \%0.55 ile Göksun ve \%0.51 ile Göynük-98 çeşidi izlemiştir. Akman-98 çeşidi ile diğer iki çeşit arasındaki fark önemli iken, Göksun çeşidi ile Göynük-98 çeşidi aynı istatistik grubunda yer almıştır. (Tablo 4).

Tablo 4. Kaolin Dozlarının ve Fasulye Çeşitlerinin Tane P İçeriğine (\%) Ait Ortalamaları

\begin{tabular}{ccccccc}
\hline Çeşitler & \multicolumn{7}{c}{ Kaolin } \\
\cline { 2 - 6 } & 0 & 2.5 & 5 & 7.5 & 10 & Ortalama \\
Göksun & 0.57 & 0.55 & 0.54 & 0.56 & 0.52 & $0.55 \mathrm{~B}$ \\
Göynük-98 & 0.54 & 0.51 & $\mathbf{0 . 4 8}$ & 0.54 & 0.51 & $0.51 \mathrm{~B}$ \\
Akman-98 & 0.59 & 0.57 & 0.58 & $\mathbf{0 . 6 4}$ & 0.56 & $0.59 \mathrm{~A}$ \\
Ortalama & 0.57 & 0.54 & 0.53 & 0.58 & 0.53 & \\
\hline LSD(çeşit): 0.03 & & &
\end{tabular}

Kaolin uygulamalarında tanede toplam $\mathrm{P}$ içeriği \%0.48-\%0.64 arasında tespit edilmiş, bununla beraber kaolin uygulamaları ve kaolin $\mathrm{x}$ çeşit interaksiyonun tanede toplam $\mathrm{P}$ içeriğine etkisi istatistiksel anlamda önemsiz bulunmuştur. Konuyla ilgili Yiğitarslan (2010), Ankara koşullarında yaptığı çalışmada Kaolin uygulamalarının tanedeki P içeriğini artırdığını belirlemiştir. Araştırmalar arasındaki farkııı̆ın çevresel faktörlerden ve uygulama farklııklarından kaynaklandığı düşünülmektedir.

\section{Tane K İçeriği (\%)}

Araştırmada ele alınan faktörlerin tanede $\mathrm{K}$ içeriğine etkisine ilişkin ortalama değerler ve istatistiksel gruplar Tablo 5'de verilmiştir. Tablodan da görüldüğü gibi tanede $\mathrm{K}$ içeriği bakımından çeşitler arasında istatistiksel olarak çok önemli $(P<0.01)$ fark görülmüştür. Çeşitlerde ortalama tanede K içerikleri \%1.68\%2.16 arasında değişim göstermiştir. En yüksek K içeriği Akman-98 çeşidinden, en düşük ise Göksun çeşidinden elde edilmiş olup, Akman-98 çeşidi hem Göksun çeşidinden hem de Göynük-98 çeşidinden çok önemli derecede üstün bulunmuştur. Bununla beraber Göksun çeşidi ile Göynük- 98 çeşidi arasında ise istatistiksel olarak fark görülmemiştir. 
Kaolin uygulamalarında tanede toplam $\mathrm{K}$ içeriği \%1.38-\%2.56 arasında tespit edilmiş ve kaolin uygulamalarının $\mathrm{K}$ içeriğine etkisi istatistiksel anlamda önemsiz bulunmuştur. Ayrıca, kaolin $\mathrm{x}$ çeşit interaksiyonuda istatistiksel olarak önemsiz bulunmuştur. Yiğitarslan (2010), Ankara koşullarında yaptığı çalışmada benzer şekilde Kaolin uygulamalarının tanedeki K içeriğine etkisinin olmadığını belirtmiştir.

Tablo 5. Kaolin Dozlarının ve Fasulye Çeşitlerinin Tane K içeriğine (\%) Ait Ortalamaları

\begin{tabular}{lcccccc}
\hline \multirow{2}{*}{ Çeşitler } & \multicolumn{7}{c}{ Kaolin } \\
\cline { 2 - 7 } & 0 & 2.5 & 5 & 7.5 & 10 & Ortalama \\
\hline Göksun & $\mathbf{1 . 3 8}$ & 2.46 & 1.41 & 1.73 & 1.42 & $1.68 \mathrm{~B}$ \\
Göynük-98 & 1.78 & 1.77 & 1.63 & 1.59 & 1.79 & $1.71 \mathrm{~B}$ \\
Akman-98 & 2.25 & 2.04 & 2.56 & 1.88 & 2.06 & $2.16 \mathrm{~A}$ \\
Ortalama & 1.80 & 2.09 & 1.87 & 1.74 & 1.76 & \\
\hline
\end{tabular}

LSD(çeşit): 0.31

\section{Tane Ca İçeriği (mg/kg)}

Denemeye alınan kuru fasulye çeşitleri ve kaolin uygulamalarının tanede toplam Ca içeriği üzerine etkisine ait ortalamalar ve istatistiksel gruplar Tablo 6 'da verilmiştir.

Tablo incelendiğinde tanede $\mathrm{Ca}$ içeriği bakımından çeşitler arasında çok önemli $(P<0.01)$ fark olduğu görülmektedir. Ca içeriği ortalama olarak en fazla $237.73 \mathrm{mg} / \mathrm{kg}$ ile Akman-98 çeşidinde görülürken en düşük 168.20 mg/kg ile Göynük-98 çeşidinde görülmüştür. En yüksek Ca değerine sahip Akman-98 ile Göksun arasındaki fark çok önemli, bu çeşitlerin Göynük-98 arasındaki fark ise önemsiz bulunmuştur. (Tablo 6).

Kaolin uygulamalarında tanede toplam Ca içeriği $155.06-265.06 \mathrm{mg} / \mathrm{kg}$ arasında tespit edilmiş ve Ca içeriğine etkisi bakımından kaolin uygulamaları ve kaolin $\mathrm{x}$ çeşit interaksiyonu istatistiksel anlamda önemsiz bulunmuştur (Tablo 6). Yiğitarslan (2010), Ankara koşullarında yaptığı çalışmada benzer şekilde Kaolin uygulamalarının tanedeki $\mathrm{Ca}$ içeriğine etkisinin istatistiksel olarak önemli olmadığını belirtmiştir.

Tablo 6. Kaolin Dozlarının ve Fasulye Çeşitlerinin Tane Ca İ̧̧eriğine (\%) Ait Ortalamaları

\begin{tabular}{lcccccc}
\hline \multirow{2}{*}{ Çeşitler } & \multicolumn{7}{c}{ Kaolin } \\
\cline { 2 - 7 } & 0 & 2.5 & 5 & 7.5 & 10 & Ortalama \\
\hline Göksun & 231.40 & $\mathbf{2 6 5 . 0 6}$ & 224.73 & 220.73 & 221.40 & $232.73 \mathrm{~A}$ \\
Göynük-98 & 182.40 & $\mathbf{1 5 5 . 0 6}$ & 171.73 & 174.06 & 157.73 & $168.20 \mathrm{~B}$ \\
Akman-98 & 247.06 & 240.73 & 247.06 & 250.06 & 203.73 & $237.73 \mathrm{~A}$ \\
Ortalama & 220.28 & 220.28 & 214.51 & 214.95 & 194.28 & \\
\hline
\end{tabular}

LSD(çeşit): 31.32

\section{Sonuç ve Öneriler}

Kaolinin kilinin tanede protein ve bazı mineral maddeler üzerine etkisinin belirlenmesi belirlenmesi amacıyla yapılan bu araştırma sonucunda çeşitler arasında tanede protein ve bazı mineral maddeler bakımından farklııkların bulunduğu gözlenmiştir. Protein oranı ve $\mathrm{N}$ içeriği bakımından Göynük-98 çeşidinin, $\mathrm{P}, \mathrm{K}$ ve Ca bakımından ise Akman-98 çeşidinin öne çıkmıştır. Göksun çeşidinde ise protein ve ele alınan mineral maddelerin ( $\mathrm{Ca}$ hariç) diğer çeşitlere göre daha düşük düzeyde olduğu tespit edilmiştir.

Kaolin uygulamalarının ise her üç fasülye çeşidinde de protein ve N, P, K, Ca gibi mineral maddelere etkisinin istatistiksel olarak önemli olmadığı belirlenmiştir.

Sonuç olarak Protein ve N bakımından Göksun-98 çeşidinin, P, K ve Ca bakımından Akman-98 çeşidinin diğer çeşitlere göre daha iyi durumda olduğu, kaolin uygulamalarının ise herhangi bir etkisinin olmadığı görülmüştür. Konu ile ilgili daha doğru bir yargıya varabilmek için bir yıllık çalışmanın yeterli olmadığı, 
farklı dozlar uygulayarak benzer çalışmaların birkaç yıl daha yürütülmesinde yarar olduğu kanaatine varılmıştır.

\section{Destek ve Teşekkür}

Bu çalışma, Prof. Dr. Nuri Yılmaz danışmanlığında Tansu Uzun tarafından tamamlanan "Bazı fasulye (Phaseolus vulgaris L.) çeşitlerinde kaolin uygulamalarının verim, verim öğeleri ve tane kalitesine etkisinin belirlenmesi" başlıklı yüksek lisans tezinden üretilmiştir (Tez No. 594811).

\section{Yazar Katkısı}

Nuri Yılmaz, araştırma için gerekli materyallerin temini, denemenin yürütülmesi, verilerin istatistiksel yorumlanması ve makalenin yazılması konularında katkıda bulunmuştur. Tansu Uzun, denemenin kurulması, yürütülmesi ve laboratuvar çalışmalarının gerçekleştirilmesi konularında katkıda bulunmuştur.

\section{Etik}

Bu makalenin yayınlanmasıyla ilgili herhangi bir etik sorun bulunmamaktadır.

\section{Çıkar Çatışması}

Yazarlar herhangi bir çıkar çatışması olmadı̆̆ını belirtmektedir.

\section{ORCID}

Nuri Yılmaz (iD https://orcid.org/0000-0002-0597-6884

Tansu Uzun (iD https://orcid.org/0000-0001-9476-6362

\section{Kaynaklar}

Cengiz, B. (2007). Sakarya ve eskişehir lokasyonlarında yetiştirilen bazı kuru fasulye çeşitlerinin kalite özellikleri [Yayımlanmamış yüksek lisans tezi]. Namık Kemal Üniversitesi.

Bremner, J. M. (1965). Total nitrogen methods of soil analysis. A. G. Norman (Ed.), Chemical and microbiological properties (s. 1149-1178) içinde. American Society of Agronomy, Inc. https://doi.org/10.2134/agronmonogr9.2.c32

Düzdemir, O. (1998). Kuru fasulye (Phaseolus vulgaris L.) genotiplerinde verim ve diğer bazı özellikler üzerine bir araştırma [Yayımlanmamış yüksek lisans tezi]. Gaziosmanpaşa Üniversitesi.

Glenn, D. M., Puterka, G. J., Vanderzwet, T., Byers, R. E. ve Feldhake, C. (1999). Hydrophobic particle films: A new paradigm for suppression of arthropod pests and plant diseases. Journal of Economic Entomology, 92(4), 759-771. https://doi.org/10.1093/jee/92.4.759

Kacar B ve İnal A (2008). Bitki analizleri. Nobel Yayın Dağıtım.

Moreshet, S., Cohen, Y. ve Fuchs, M. E., (1979). Effect of Increasing foliage reflectance on yield, growth, and physiological behavior of a dryland cotton crop. Crop Science 19, 863-868. https://doi.org/10.2135/cropsci1979.0011183X001900060029x

Pekşen, E., (2005). Samsun koşullarında bazı fasulye (Phaseolus vulgaris L.) genotiplerinin tane verimi ve verimle ilgili özellikler bakımından karşılaştırılması. OMÜ Ziraat Fakültesi Dergisi, 20(3), 88-95. https://doi.org/10.7161/anajas.2005.20.3.88-95

Rosati, A., Metcalf, S. G., Buchner, R. P., Fulton, A. E. ve Lampinen, B. D., (2006). Physiological effects of kaolin applications in well-irrigated and water-stressed walnut and almond trees. Annals of Botany, 98, 267-275. https://doi.org/10.1093/aob/mcl100 
Şehirali, S. (1979). Yemeklik tane baklagiller (s. 8-65). T.C. Tarım ve Orman Bakanlığı Ziraat İşleri Genel Müdürlüğü Yayınları.

Soundara Rajan, M.S., Ramkumar Reddy, K., Sudhakar Rao, R. ve Sankara Reddi, G.H. (1981). Effect of antitranspirants and reflectants on pod yield of rainfed groundnut. Agricultural Science Digest 1, 205-206. https://agris.fao.org/agris-search/search.do?recordID=US201302625684

Srinivasa Rao, N. K. (1986). The effects of antitranspirants on stomatal opening, and the proline and relative water contents in the tomato. Journal of Horticultural Science 61, 369-382. https://doi.org/10.1080/14620316.1986.11515715

Stanhill, G., Moreshet, S. ve Fuchs, M. (1976). Effect of increasing foliage and soil reflectivity on the yield and water use efficiency of grain sorghum. Agronomy Journal 68, 329-332. https://doi.org/10.2134/agronj1976.00021962006800020031x

Uysal, F. (2002). Kalite fonksiyonun Türkiye'de baklagil dış satımına etkileri [Yayımlanmamış yüksek lisans tezi]. Akdeniz Üniversitesi.

Ünver, S., Kaya, M. ve Atak, M. (1999). Geçmişten günümüze yemeklik baklagiller tarımı. Türk-Koop. Ekin Dergisi, 3(7), 40-44.

Vanoğlu, T.G. (2015). Okitsu wase satsumalarında farklı doz ve zamanlardaki kaolin uygulamalarının bazı morfolojik, fizyolojik, verim ve kalite özelliklerine etkileri [Yayımlanmamış yüksek lisans tezi]. Mustafa Kemal Üniversitesi.

Yiğitarslan, U. (2010). Fasulye'de kaolin uygulamasının verim, verim öğeleri ve tane kalitesine etkisinin belirlenmesi [Yayımlanmamış yüksek lisans tezi]. Ankara Üniversitesi. 